\title{
New Insights into Various Production Characteristics of Streptococcus thermophilus Strains
}

\author{
Yanhua Cui ${ }^{1, *}$, Tingting $\mathrm{Xu}{ }^{1}$, Xiaojun $\mathrm{Qu}{ }^{2}$, Tong $\mathrm{Hu}^{1}{ }^{1}, \mathrm{Xu} \mathrm{Jiang}{ }^{1}$ and Chunyu Zhao ${ }^{1}$ \\ 1 Department of Food Science and Engineering, School of Chemistry and Chemical Engineering, \\ Harbin Institute of Technology, Harbin 150090, China; xutingting@gmail.com (T.X.); \\ tonghu1992715@gmail.com (T.H.); jiangxu2016@gmail.com (X.J.); zhaochunyuhit@yeah.net (C.Z.) \\ 2 Institute of Microbiology, Heilongjiang Academy of Sciences, Harbin 150010, China; qvxiaojun@163.com \\ * Correspondence: yhcui@hit.edu.cn; Tel.: +86-451-8628-2902
}

Academic Editor: Vladimír Křen

Received: 2 August 2016; Accepted: 23 September 2016; Published: 12 October 2016

\begin{abstract}
Streptococcus thermophilus is one of the most valuable homo-fermentative lactic acid bacteria, which, for a long time, has been widely used as a starter for the production of fermented dairy products. The key production characteristics of $S$. thermophilus, for example the production of extracellular polysaccharide, proteolytic enzymes and flavor substances as well as acidifying capacity etc., have an important effect on the quality of dairy products. The acidification capacity of the strains determines the manufacturing time and quality of dairy products. It depends on the sugar utilization ability of strains. The production of extracellular polysaccharide is beneficial for improving the texture of dairy products. Flavor substances increase the acceptability of dairy products. The proteolytic activity of the strain influences not only the absorption of the nitrogen source, but also the formation of flavor substances. Different strains have obvious differences in production characteristics via long-time evolution and adaptation to environment. Gaining new strains with novel and desirable characteristics is an important long-term goal for researchers and the fermenting industry. The understanding of the potential molecular mechanisms behind important characteristics of different strains will promote the screening and breeding of excellent strains. In this paper, key technological and functional properties of different $S$. thermophilus strains are discussed, including sugar metabolism, proteolytic system and amino acid metabolism, and polysaccharide and flavor substance biosynthesis. At the same time, diversity of genomes and plasmids of $S$. thermophilus are presented. Advances in research on key production characteristics and molecular levels of S. thermophilus will increase understanding of molecular mechanisms of different strains with different important characteristics, and improve the industrialization control level for fermented foods.
\end{abstract}

Keywords: Streptococcus thermophilus; genomics; plasmid; production characteristics

\section{Introduction}

Streptococcus thermophilus is the only streptococcal species widely used in food fermentations, especially for yogurt manufacturing. It has been used as a seed along with Lactobacillus delbrueckii subsp. bulgaricus to produce yogurt for thousands of years. At the same time, $S$. thermophilus has also been used in various artisanal and industrial dairy products, for example some cheeses and fermented milk [1,2]. It can improve the texture and flavor properties of these dairy products, and accelerate the acidifying rate of dairy products. Additionally, $S$. thermophilus is found to have various probiotic effects, including antioxidant activities, modulation of intestinal microbiota, inhibition of specific pathogens etc. [1,2]. This species has attracted broad interest in past decades because of its industrial application and probiotic effects. 
The production characteristics of $S$. thermophilus, such as acidifying capacity, proteolytic activity, fast growth, production of exopolysaccharide (EPS), bacteriocins and flavor substances, antiphage, and host defense ability etc. directly or indirectly affect the quality of fermented dairy products [2-7]. The acidifying capacity, proteolytic activity, EPS and flavor production abilities are key production characteristics of strains. The rate of acidification is the most important criteria for evaluating whether or not $S$. thermophilus is a good starter culture for use in fermented dairy products. It determines the fermenting time and quality of fermented dairy products $[2,4,6]$. The acidifying capacity of strains is closely related with their sugar utilization ability. EPSs play an important role in improving the viscosity, texture and mouthfeel of dairy products [2-4,7]. Therefore, high EPS production is one of the most important and attractive properties of $S$. thermophilus strains. Flavor is a key factor determining the acceptability and preference of dairy products. The proteolytic system of $S$. thermophilus can degrade casein, which is an important precursor of flavor compounds. Furthermore, the proteolytic activity of strain has a tight correlation with its acidifying capacity [6].

In order to adapt to different environments, genomes of different $S$. thermophilus strains were found to change during evolution, and form unique genetic compositions and special corresponding control systems. For example, some excellent industrial strains genomes contain distinctive eps gene clusters that are responsible for EPS production [2-4,7]. Strains also show different fermentation characteristics, including the ability to produce acid, adaptability to environmental stress, protein decomposition ability, sugar utilization ability, EPS and bacteriocin production abilities etc. [3-9].

At present, most studies on $S$. thermophilus focus on the analysis of diversity based on phenotypic characteristics [3-9]. However, emerging tools for synthetic biology have led to a number of strategies for metabolic engineering. The potential molecular mechanisms behind important characteristics of different strains have been partially reported.

\section{Diversity of Genomes and Plasmids of S. thermophilus}

\subsection{Diversity of S. thermophilus Genomes}

The genome sequence information of some strains of S. thermophilus was recently published [10-18]. This accelerates research on $S$. thermophilus at the molecular level. The entire genomes of 14 S. thermophilus strains (LMG18311, JIM8232, CNRZ1066, LMD-9, MN-ZLW-002, ND03, ASCC 1275, SMQ-301, MN-BM-A02, MN-BM-A01, S9, KLDS MS, CS8, and KLDS 3.1003) have been fully sequenced [10-18]. These strains were all isolated from fermented milk or milk [10-18]. S. thermophilus strains MTH17CL396, M17PTZA496, TH1435, TH1436, TH982, TH1477, 1F8CT, and TH985 have been completely sequenced at the chromosome level [19-21]. Meanwhile, some genome strains have finished draft, including CNCM I-1630, MTCC5460, MTCC5461, DGCC7710, and C106 [22-24]. The genomes range in size from $1.609-2.065 \mathrm{Mb}$ with $1476-2193$ proteins.

The evolution of $S$. thermophilus in milk environment is mainly via gene horizontal transfer and natural competition. In the process of evolution, some carbohydrate metabolism genes, virulence genes and other genes gradually degrade and disappear in the stable milk environment [6,25-27]. The virulence genes in other streptococci are either non-functional or completely absent in S. thermophilus [6,25-27]. S. thermophilus contains genes for glycolytic pathway, the non-oxidative branch of the pentose phosphate pathway, and pyruvate metabolism. It does not have the pyruvate carboxylase-encoding gene, which is required for the formation of oxaloacetate from pyruvate. Functional gene distribution analysis of the open reading frame group showed that the $S$. thermophilus LMG18311, LMD-9 and CNRZ1066 strains form obvious functional clusters, which specifically adapt to the nutrition of the milk environment [25]. S. thermophilus strains show obvious differences to other Streptococcus species in genome [6,25-27].

Some research indicates that the proteolytic system, nitrogen metabolism, sugar utilization and transporter systems of $S$. thermophilus are very important during the adaptation to milk environments $[3,6,15,25,28]$. Research on 47 strains of $S$. thermophilus isolated from dairy by means 
of comparative genome hybridization analysis has found that the core genes of the different strains genomes are different. The differences of core genes were mainly the biosynthesis of bacteriocin and EPS, peptide metabolism, and phage resistance related genes etc. [28]. This evolution has led to the various metabolic activities of different $S$. thermophilus strains [3-9].

\subsection{Plasmid Diversity of S. thermophilus}

As a self-replication DNA molecule, plasmids do not have the necessary genetic material for the survival of bacteria, but they often carry some special genes which confer important traits for strains, for example, casein utilization, EPS biosynthesis, potassium transport, bacteriophage resistance, and bacteriocin production related genes etc. [29]. Compared with some lactic acid bacteria (LAB) that contain plenty of plasmids, for example Lactobacillus plantarum and Lactococcus lactis etc., S. thermophilus strains carry very few plasmids (Table A1, http:/ /www.ncbi.nlm.nih.gov) [29,30].

Most $S$. thermophilus strains do not contain plasmids. Some strains have no more than 2 plasmids, which range in size from 2.67 to $8.14 \mathrm{~kb}$. To date, most plasmids of $S$. thermophilus have no apparent phenotypic traits. Some plasmids encode small heat shock proteins, including pER341 [31], pCI65st [32], pND103 [33], pST04 and pER1-1 [34], pt38 [35], pER7, pER16, pER26, pER35, pER36, and pER41 [36,37]; p2, pK1002C2, and pK2007C6 [12]. Amino acid sequence comparisons of the small heat shock proteins and of the replication proteins from pER16, pER35, and pER36 revealed a high degree of identity suggesting a common origin [37]. Some research indicates that small heat shock proteins are induced by elevated temperatures and low $\mathrm{pH}$, and expression of these proteins can increase the viability of bacteria in extreme environments [34,37]. Therefore the promoter of heat shock protein gene $h s p 16.4$ of pER341 is under investigation for potential use in temperature-controlled expression of heterologous genes in LAB [31]. There are restriction modification system-related genes in plasmids pCI65st [32], pSt08, pSt0 [34], and pER35 [37].

Generally plasmids replicate via the rolling circle replication (RCR) and $\theta$ mode of replication. The mode of replication of plasmids has a close relationship with some important characteristics of plasmid-derived vectors, including host range, stability, and copy number etc. [29]. RCR plasmids are usually small in size (less than $10 \mathrm{~kb}$ ), have multiple copies, and are tightly organized. However, $\theta$ plasmids have better structural stability than RCR plasmids. Most plasmids from $S$. thermophilus replicate via RCR. Most RCR plasmids of S. thermophilus belong to the pC194 family, however pSMQ172 has been assigned to the pE194/pMV158 family [38]. Although plasmids pSMQ-316 and pSMQ-312b are less than $10 \mathrm{~kb}$, they replicate via $\theta$-replicating mode [39].

\section{Technological and Functional Properties of S. thermophilus}

\subsection{Sugar Metabolism}

In industrial fermentation processes, the rates of milk acidification by S. thermophilus species are of major technological importance. The acidification rate of strains depends on their sugar utilization ability. A number of works indicate that utilization of glucose, lactose and fructose by $S$. thermophilus is a common characteristic in all existing studies, while galactose, mannose, sucrose, maltose, melibiose, and raffinose utilizations have variable profiles [40-47]. At the same time, it has been found that carbohydrate metabolism is essential for the colonization of $S$. thermophilus in the digestive tract of gnotobiotic rats [48]. Colonization ability is an important determining factor for developing bacterial health function in humans. A detailed description of sugar metabolism and central carbon pathways in $S$. thermophilus is presented in Figure 1.

S. thermophilus prefers lactose over glucose as a major carbon and energy source. The lac operon controls the transport and hydrolysis of lactose, and its transcription is induced during growth on lactose. It encodes lactose permease (LacS) and cytoplasmic $\beta$-galactosidase (LacZ). Lactose is cleaved into glucose and galactose by LacZ. Glucose is phosphorylated by glucokinase to glucose-6-phosphate, and then is further utilized through the glycolysis pathway. Galactose is 
converted to glucose-1-phosphate by means of the Leloir pathway, which consists of the regulator GalR, galactokinase (GalK), galactose-1-phosphate uridyltransferase (GalT), UDP-glucose-4-epimerase (GalE), and galactosemutarotase (GalM). They were found to be organized in the galRKTEM gene cluster $[49,50]$.

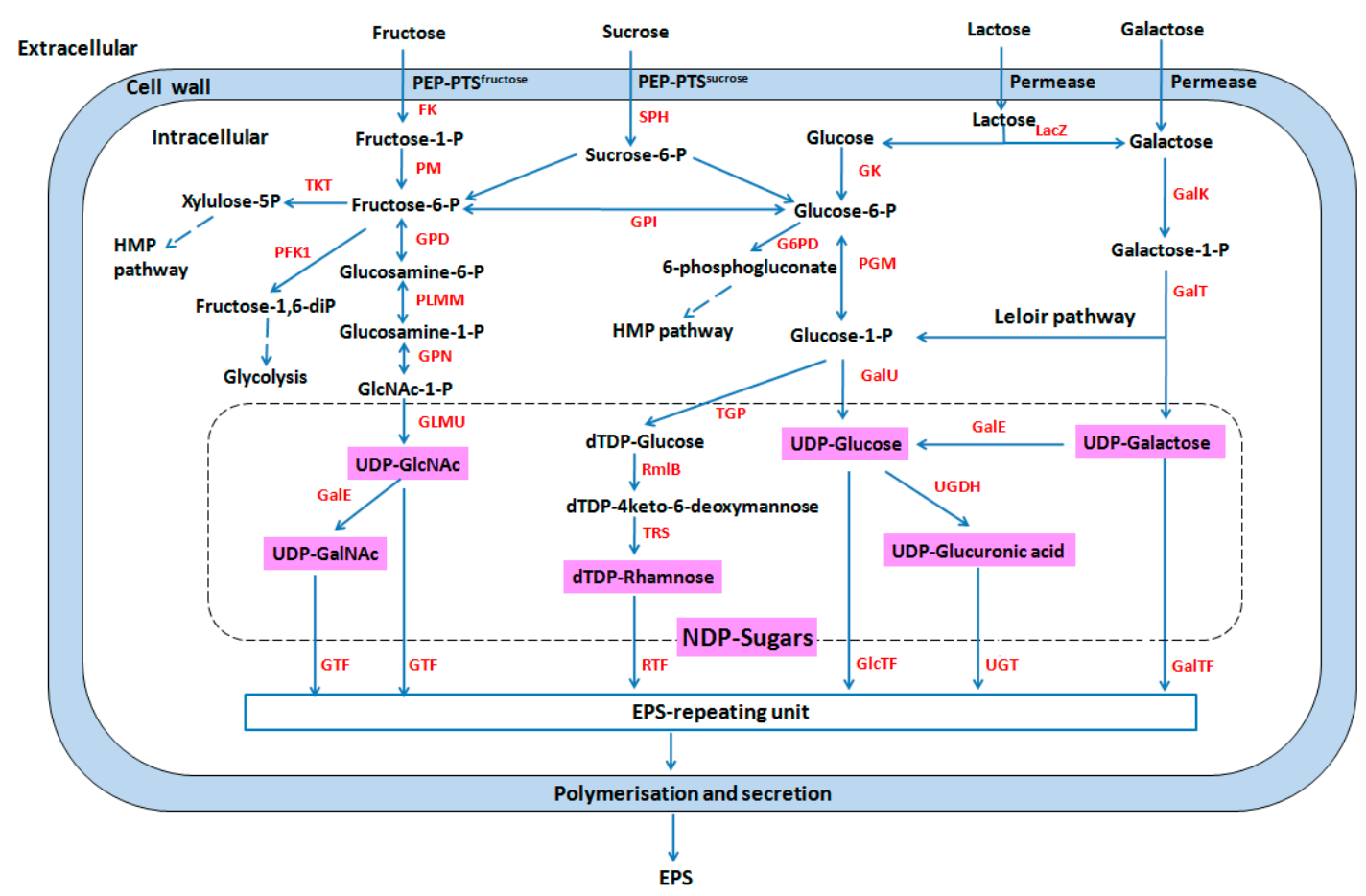

Figure 1. Pathways of sugar metabolism and exopolysaccharide (EPS) biosynthesis in S. thermophilus. FK: fructokinase; G6PD: glucose-6-phosphate dehydrogenase; GalE: UDP-galactose-4-epimerase; UGDH: UDP-glucose 6-dehydrogenase; GalK: galactokinase; GalT: galactose-1-phosphate uridylyltransferase; GalTF: galactosyltransferase; GalU: UDP-glucose pyrophosphorylase; GK: glucokinase; GlcTF: glucosyltransferase; GLMU: N-acetylglucosamine-1-phosphate uridyltransferase; GPD: glucosamine-6-phosphate deaminase; GPI: glucose-6-phosphate isomerase; GPN: glucosamine-1phosphate $N$-acetyltransferase; GTF: glycosyltransferase; HMP pathway: pentose phosphate pathway; LacZ: $\beta$-glalactosidase; MPI: mannose-6 phosphate isomerase; NDP sugars, nucleotide sugars; PEP: phosphoenolpyruvate; PFK1: phosphofructokinase; PGM: $\alpha$-phosphoglucomutase; PLMM: phosphoglucosamine mutase; PM: phosphomutase; PTS: sugar phosphotransferase system; RmlB: dTDP-glucose 4, 6-dehydratase; RTF: rhamnosyltransferase; SPH: sucrose-6-phosphate hydrolase; TGP: dTDP-glucose pyrophosphorylase; TKT: transketolase; TRS: dTDP-4-dehydrorhamnose 3,5-epimerase; UDP-GalNAc: UDP-N-acetylgalactosamine; UDP-GlcNAc: UDP- $N$-acetylglucosamine; UGT: UDP-glucuronosyltransferase. Double headed arrow indicates the bidirectional reaction; dashed arrows indicate a part pathway; arrow indicates a reaction; red fonts indicates enzyme; words with red background color indicate the NDP sugars.

The gal promoter plays an important role in the galactose phenotype of S. thermophilus [42,50-54]. It has been found that the point mutations in the promoter region of gal operon lead to low expression level of the Leloir pathway enzymes for galactose utilization [42,50]. At the same time, some studies demonstrate that the low level of galactokinase (GalK) activity in galactose negative strains with respect to galactose positive strains indicate poor galK translation, which was related to nucleotide differences in the ribosome binding site [42,51]. One class of Gal-positive mutants described by Vaughan et al. contained a G-to-A substitution in the -10 box of galK that turned out to be a promoter up mutation [50]. Recently, it was found that spontaneous galactose-fermenting mutant St1- $-\mathrm{Ga}^{+}-1$ has the same mutation in the -10 region of galK, i.e., TACAAT, which is closer to the consensus sequence 
TATAAT. Strain St1-Ga+ ${ }^{+} 1$ can ferment galactose, while its mother strain St1-WT is unable to utilize galactose, although it has intact galKTEM genes [54]. At the same time, Sørensen et al. found that another spontaneous galactose-fermenting mutant $\mathrm{St} 2-\mathrm{Ga}^{+}-1$ had a C-to-A mutation between the -10 region and the galK transcription initiation site [54]. It was speculated that this mutation might increase the "opening potential" for the -9 to +3 region, and then lead to creating a stronger promoter [54].

The utilization of galactose is a desirable property for strains used in industrial dairy fermentations. Galactose accumulation leads to the growth of undesirable LAB in milk products, and cheese browning during baking. Gal-positive $S$. thermophilus strains can inhibit the growth of undesirable $\mathrm{LAB}$, and prevent the browning defects [40-43]. Furthermore, galactose utilization enhances EPS production. Galactose utilization can produce nucleotide sugars, which are EPS precursors and whose low level might be a potential bottleneck in EPS production $[55,56]$. At the same time, high level of galactose consumption may lead to accumulation of toxic galactitol in human tissue cells [57]. Galactose utilization in strains decreases galactose content in dairy products, which is beneficial for human health.

\subsection{Polysaccharide Biosynthesis}

Extracellular polysaccharides are produced by a variety of bacteria, and are present as capsular polysaccharides (CPSs) or EPSs. The former are tightly linked to the surface of the microbial cell, the latter are released into the growth medium during bacteria growth and are not attached permanently to the cell surface. Most $S$. thermophilus strains can synthesize EPSs [58]. Additionally some $S$. thermophilus strains may produce CPSs [59].

EPS production is one of the most important properties of $S$. thermophilus, especially dairy strains. EPSs act as in situ-produced natural biothickeners that can improve the viscosity, texture and mouthfeel of the dairy products, and prevent syneresis in yogurt [60-62]. EPSs from $S$. thermophilus benefit the health of host animals, and enhance the immune responses of host animals [63-66]. It is speculated that immunoregulatory effects of EPSs are related to their chemical composition.

EPSs are long-chain polysaccharides consisting of branched, repeating units of sugars or sugar derivatives. They are classed into homopolysaccharides that consist of a single type of sugar, and heteropolysaccharides with repeating units consisting of different sugars. Most S. thermophilus strains synthesize heteropolysaccharide [58]. S. thermophilus EPSs are predominantly composed of galactose, glucose, and rhamnose in different ratios. Additionally, acetyl-galactosamine, fucose, and acetylated galactose moieties have also been found in S. thermophilus EPSs [67,68]. Generally, the structures of EPS have a close relationship with their functions. Therefore, the highly polymorphic structures of EPSs maybe confer a broad application potential [3,69]. A detailed description of EPS biosynthesis in S. thermophilus has been presented in Figure 1.

Sugar nucleotides act as precursor molecules of EPSs, and offer sugar residues in the glycosylation reactions that produce polysaccharides [70,71]. The biosynthesis of EPSs is regulated and determined by eps gene cluster. EPS production is associated with plasmids in L. lactis [72]. However, all eps gene clusters of $S$. thermophilus are located on the chromosome. Generally, the eps gene clusters contain genes involved in regulation of EPS production (eps $A, e p s B)$, chain-length determination of EPS (epsC, epsD), formation of the repeating units (epsE, epsF, epsG, epsH, and epsI), and EPS polymerization and export (epsK, epsL, and epsM) [58,73]. The 5' end of eps gene clusters is the deoD gene, which putatively encodes purine nucleotide phosphorylase and is presumably involved in the biosynthesis and catabolism of nucleotides. It has been documented that the orf14.9 gene distributed downstream of most eps gene clusters is associated with the cell growth of $S$. thermophilus [7].

The structural diversity of EPSs molecules is correlated with the genetic diversity of the eps locus. At least 20 distinct types of eps gene clusters were found in 51 S. thermophilus strains known to date [7,15-24]. The diversity of eps gene cluster may have a direct effect on the EPS production capacity of the strain. To date, distribution of regulatory and structural genes is conserved in known eps cluster of $S$. thermophilus strains $[7,15,70]$. 
Sugar nucleotides are assembled into a repeating unit by means of multiple glycosyltransferases (GTFs). At least 67 GTFs have been found in 51 S. thermophilus strains known to date [7,15-24]. GTF determines the monosaccharide composition of EPS. Indeed, the number of GTFs present in eps gene clusters will correspond more or less to the number of monosaccharide units present in the various structures of the corresponding heteropolysaccharides repeating units [74-76].

Recently a novel eps cluster deoDepsAB1C1DEFGHIJ2C2DKLMNOrf14.9epsOPQ was identified in S. thermophilus ASCC 1275 (ST 1275) [15]. The strain produces about $1029 \mathrm{mg} / \mathrm{L}$ in milk medium in the presence of $0.5 \%$ whey protein concentrate [77]. This is the highest known EPS yield of all the reported data on S. thermophilus. The ASCC 1275 strain produced not only CPS but also EPS. The former does not cause ropiness in milk products, whereas the latter contributes to the enhanced texture of milk products [62]. The EPS produced from ST 1275 exhibited texture modifying properties in Mozzarella cheese and yogurt $[62,78,79]$.

The eps gene cluster of ASCC 1275 contains highly conserved regulatory genes (eps $A, e p s B$ ) and chain-length determination related genes (eps1C, eps1D) [15]. At the same time, this cluster has GTF genes (epsE, epsF, epsG, epsH, epsI, epsJ and epsK), which may transfer various nucleotide sugars including UDP-glucose, UDP-galactose, dTDP-rhamnose, UDP-GlcNAc and UDP-galactofuranose to form the repeating units [15]. Interestingly, an additional eps $2 C-e p s 2 D$ was found in this cluster, which was probably involved in the chain length determination. Additionally, the eps cluster contains a unique UDP-galactopyranose mutase, which is responsible for the synthesis of UDP-galactofuranose [15]. It is rarely found in the $S$. thermophilus eps gene cluster [18].

The EPS production ability of $S$. thermophilus is affected by two factors, i.e., strain dependent and cultivation conditions, such as temperature, carbon sources, nitrogen sources, and $\mathrm{pH}$, etc. [77,80,81]. In general, the amount of EPS produced by S. thermophilus is at relatively low levels, i.e., 50 to $400 \mathrm{mg} / \mathrm{L}$ in milk medium.

The EPS yield of $S$. thermophilus $05-34$ reaches $250 \mathrm{mg} / \mathrm{L}$ in $10 \%$ reconstituted skim milk with $80 \mathrm{~g} / \mathrm{L}$ sucrose and $30 \mathrm{~g} / \mathrm{L}$ soy peptone at an initial $\mathrm{pH} 7.0$ and $37^{\circ} \mathrm{C}$ for $30 \mathrm{~h}$ [81]. The research indicated that the molecular mass of EPS is $4.7 \times 10^{5} \mathrm{Da}$, which is increased by 9 times compared with non-optimal fermentation conditions, while monosaccharide composition does not change. Additionally, real-time quantitative PCR analysis indicated that the transcription level of chain length determination related gene epsC was up-regulated 2.7-fold. It was speculated that the improved degree of polymerization of monosaccharide led to increasing molecular mass of EPS. The results demonstrated that the optimized fermentation conditions can not only increase the EPS yield, but also improve EPS molecular mass.

Instability of EPS production and variability of polymer yields are common in the dairy industry. Generally, it is thought that this genetic instability is due to loss of the encoding eps genes plasmid in L. lactis. However, it is speculated that insertion sequences (IS) or transposase genes lead to the instability in S. thermophilus [73]. The eps gene cluster of some strains contains transposable elements, such as IS sequences or transposase genes. S. thermophilus MN-ZLW-002 was isolated from a traditional fermented dairy food, and has a prominent EPSs production ability [14]. Interestingly, its eps gene cluster contains 9 transposases genes. The eps cluster of $S$. thermophilus CNRZ368 consists of $32.5 \mathrm{~kb}$, contains 25 ORF (open reading frame) and six intact or truncated ISs belonging to four different families, ISS1, IS981, IS1193 and IS1194 [73]. S. thermophilus ND03 genome carries a unique 23.4-kb eps gene cluster (STND_1010 to STND_1035), which contains 10 EPS-related genes (epsA, epsB, epsC, epsD, epsE, epsF, epsG, epsI, epsJ, and epsP) and seven intact or truncated ISs [13]. The eps clusters of S. thermophilus CNRZ1066 and LMG 18311 have 2 and 3 transposase genes, respectively [10]. These ISs or transposases increase the instability of EPS production by means of the transposition of mobile elements. Additionally, instability of EPS production in S. thermophilus is related to generalized genomic instability [82]. 


\subsection{Proteolytic System and Amino Acid Metabolism}

The growth of LAB is limited due to the low free amino acids in milk. Milk contains an abundance of proteins. Therefore, the strains must utilize proteins, produce peptides and amino acids to satisfy its nitrogen source requirement during rapid growth in milk. The protein hydrolysis system provides the basic amino acids for the growth of the cells, and also affects the sensory characteristics and flavor of fermented dairy products [83].

The proteolytic system of LAB mainly consists of (i) an extracellular cell anchored protease capable of casein hydrolysis; (ii) a set of amino acid and peptide transport systems required for import of amino acids and (iii) a set of intracellular peptidases involved in the hydrolysis of casein-derived peptides essential for various housekeeping processes peptides transporters, and intracellular peptidases $[2,4,25,84]$. Recently, analysis of LAB genome sequences revealed the presence of up to 40 putative proteolytic enzymes per bacterial species, the role of more than half of them being still unknown [15-24,83]. In addition, recent data indicate that proteolysis at LAB surface is much more intense than expected so far.

The proteinase type and proteolytic activity of LAB have obvious differences $[85,86]$. At present, it is found that five types of extracellular proteinases in LAB, including PrtP (L. lactis, Lactobacillus paracasei), $\operatorname{PrtH}$ (Lactobacillus helveticus), PrtR (Lactobacillus rhamnosus), PrtS (S. thermophilus), $\operatorname{PrtB}$ (L. delbrueckii ssp. bulgaricus) [83]. The proteolytic system of $S$. thermophilus comprises more than 20 proteolytic enzymes, including cell-wall bound proteinase PrtS, endopeptidases (PepO, PepF), dipeptidases (PepD, PepV), tripeptidase PeoT, and proline peptidases (PeoX, PeoP, PepQ) etc. (Figure 2).
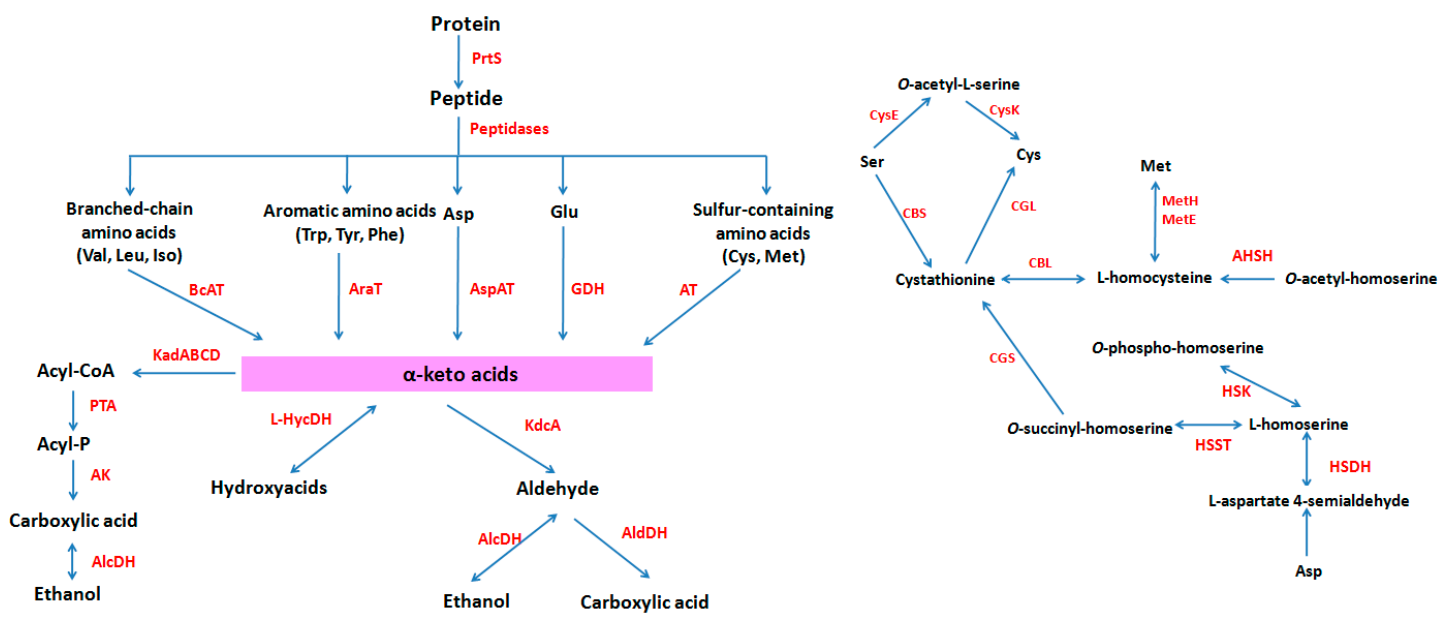

Figure 2. Proteolytic system and amino acid metabolism in S. thermophilus. AHSH: O-acetylhomoserine sulfhydrylase; AK: acyl kinase; AlcDH: alcohol dehydrogenase; AldDH: acetaldehyde dehydrogenase; AraT: aromatic aminotransferase; Asp: aspartate; AspAT: aspartate transaminase; AT: aminotransferase; BcAT: branched-chain aminotransferase; CBL: cystathionine $\gamma$ lysase; CBS: cystathionine $\beta$ synthase; CGL: cystathionine $\beta$ lysase; CGS: cystathionine $\gamma$ synthase; Cys: cysteine; CysE: serine $O$-acetyltransferase; CysK: O-acetylserine sulfhydrylase; GDH: glutamate dehydrogenase; Glu: glutamate; HSDH: homoserine dehydrogenase; HSK: homoserine kinase; HSST: homoserine O-succinyltransferase; Iso: isoleucine; KadABCD: keto acid dehydrogenase complex; KdcA: keto acid decarboxylase; Leu: leucine; L-HycDH: L-hydroxyacid dehydrogenase; Met: methionine; MetE: homocysteine methyltransferase; MetH: homocysteine $S$-methyltransferase; Phe: phenylalanine; PTA: phosophotransacylase; Ser: serine; Trp: tryptophan; Tyr: tyrosine; Val: valine. Double headed arrow indicates the bidirectional reaction; arrow indicates a reaction; red fonts indicates enzyme; words with red background color indicate the important intermediate products ( $\alpha$-keto acids). 
Additionally, there are great differences in the proteolytic activity of the different strains [6,47,87-89]. Galla et al. (2009) evaluated proteolytic and acidifying properties of 30 S. thermophilus strains isolated from yoghurt or cheeses [6]. Among 30 strains tested, 12 exhibited cell envelope-associated proteinase activity $\left(\mathrm{PrtS}^{+}\right)$, three displayed slight $\mathrm{PrtS}$ activity $\left(\mathrm{PrtS}^{+/-}\right)$. Interestingly, 8 strains had no proteinase activity, though they contained corresponding gene prtS. It is speculated that the absence of PrtS activity in the $\mathrm{PrtS}^{-}$strain probably results from an alteration of the $p r t S$ regulation.

The previous studies indicated that there was a tight correlation between the high acidifying capacity and high proteolytic activity of strains $[6,89]$. These results indicated that the presence of high proteinase activities allowed strains to grow and produce acid more rapidly in milk. The types of 16S-23S intergenic spacer (ITS) region sequences were related with the same phenotypic properties [6]. At present, four types were found in S. thermophilus, including ITS-St-I, ITS-St-II, ITS-St-III, and ITS-St-IV [90]. ITS-St-I and ITS-St-II types are common types. Galia et al. found that most strains had an ITS-St-I allele (17 out of 30) or an ITS-St-II allele (10 out of 30) while only three exhibited an ITS-St-V allele [6]. Generally, strains with an ITS-St-II allele exhibited the high proteolytic and acidifying capacities, whereas strains with an ITS-St-I allele displayed slight PrtS activity or no PrtS activity [6].

\subsection{Flavor}

Flavor is one of the most important properties of food products, and is a key factor in determining acceptability and preference [91]. More than 100 different flavor compounds are found in yogurt, including alcohols, aldehydes, ketones, acids, esters, lactones, sulfur-containing compounds, and heterocyclic compounds etc. [91,92]. These flavor compounds include the volatiles already present in the milk and specific flavor compounds produced from milk fermentation [92-94]. Lactic acid, acetaldehyde, diacetyl, acetoin, acetone, and 2-butanone are important flavor compounds, and are responsible for typical aroma and flavor of yogurt [91-94].

LAB play an important role in flavor formation during the fermentation of dairy products. Flavor-forming capacity is an important evaluating indicator of starter culture in fermented dairy. The flavor of dairy products originated from protein, fat and carbohydrate in the milk. Casein is the main precursor of flavor compounds when LAB are growing in milk [94]. Casein is degraded into its constituent amino acids by means of proteolytic system of LAB. Then, free amino acids are converted to various flavor compounds, such as aldehydes, alcohols, and esters [91,94]. The flavor compounds are mainly from the branched-chain amino acids, the aromatic amino acids, and the sulfur-containing amino acids [94-97]. These amino acids convert into flavor compounds mainly via transamination route, which uses an $\alpha$-keto acid as an amino group acceptor for the amino transferases. Some enzymes involved in the transamination route of amino acid degradation have been found in S. thermophilus genomes, including branched-chain aminotransferase (BcAT), glutamate dehydrogenase $(\mathrm{GDH})$, alcohol dehydrogenase $(\mathrm{AlcDH})$, keto acid dehydrogenase complex, phosphotransacylase (PTA), L-hydroxyacid dehydrogenase (L-HycDH), and esterase A (EstA) [10,12,94]. Research indicates that $S$. thermophilus exhibits glutamate dehydrogenase activity, which produces $\alpha$-ketoglutarate from glutamate, and consequently is capable of catabolizing amino acids in the reaction medium without $\alpha$-ketoglutarate addition [98].

The level of flavor compounds could be improved using molecular biotechnology. The ability to generate important metabolites of $S$. thermophilus is improved by expression of $\alpha$-acetolactate synthase gene (als) and alcohol dehydrogenase gene (adhB) [99]. High levels of 2,3-butanediol and ethanol are obtained by over expressing the als gene or $a d h B$ gene in $S$. thermophilus [99]. These metabolites improve the flavor of dairy product.

Extraction and analysis of flavor compounds via traditional methods is time-consuming. Recently fermentation time, acid and flavor substance formation of 43 strains of $S$. thermophilus were evaluated. At the same time, a multilocus sequence typing analysis of 8 functional genes associated with 
production of acetaldehyde and diacetyl was performed including serine hydroxymethyltransferase gene, acetate kinase gene, L-lactate dehydrogenase gene, pyruvate decarboxylase gene, serine hydroxymethyltransferase gene, NADH oxidase gene, pyruvate formate-lyase gene, and pyruvate dehydrogenase gene. It was found that the grouping based on functional genotype were consistent with that of derived from the phenotyping characteristics [100]. A similar result was obtained in the research on L. delbrueckii ssp. bulgaricus [101]. The results indicated that functional gene multilocus sequence typing technology can be used to predict the fermentation and flavor-producing characteristics of yogurt-producing bacteria $[100,101]$.

\section{Conclusions}

Sugar utilization ability, EPS and flavor substance production ability, and proteolytic activity are important production characteristics of $S$. thermophilus. They determine the quality of fermented dairy products. Different $S$. thermophilus strains show diversity in their production characteristics. A great deal of information on genomes and plasmids of $S$. thermophilus has been published. This accelerates people's understanding of the potential molecular mechanisms behind important characteristics of different strains. Generally, the different strains with different production characteristics have obvious differences in their genomes. The differences are mainly involved in the biosynthesis of bacteriocin and EPS, peptide metabolism, and phage resistance related genes etc.

The sugar utilization ability of strains determines the acidification rate of fermented milk. The gal promoter plays an important role in the galactose utilization of $S$. thermophilus, which is a desirable property for strains. The point mutations in the promoter region of gal operon lead to low expression level of galactose utilization related enzymes. EPS can improve the texture of fermented milk products. The eps gene cluster is responsible for the biosynthesis and regulation of EPS. The eps gene clusters of $S$. thermophilus have abundant genetic diversity, which has a close relationship with the structure and yield of EPSs. PrtS is most important proteinase of $S$. thermophilus. Most strains contain prtS gene. However, some $p r t S$ genes do not have activity because of the alteration of the $p r t S$ regulation. Casein is the main precursor of flavor compounds in fermented milk products. The proteolytic system plays a crucial role in the formation of flavor compounds. Although the potential molecular mechanisms behind important characteristics of different strains have been reported partially, further research is needed in order to reveal the full molecular mechanisms.

Acknowledgments: This work was supported by National Nature Science Foundation of China (Grant No. 31471712; 31371827).

Author Contributions: Yanhua Cui and Tingting $X u$ developed the ideas presented in this manuscript, collected the literature and wrote the manuscript; Tong Hu, $\mathrm{Xu}$ Jiang, and Chunyu Zhao collected corresponding data; and drew Figures 1 and 2, and Table A1. Xiaojun Qu professionally approved the manuscript.

Conflicts of Interest: The authors declare no conflict of interest.

\section{Abbreviations}

$\begin{array}{ll}\text { AlcDH } & \text { Alcohol dehydrogenase } \\ \text { BcAT } & \text { Branched-chain aminotransferase } \\ \text { CPSs } & \text { Capsular polysaccharides } \\ \text { EPSs } & \text { Exopolysaccharides } \\ \text { EstA } & \text { Esterase A } \\ \text { GDH } & \text { Glutamate dehydrogenase } \\ \text { GTFs } & \text { Glycosyltransferases } \\ \text { IS } & \text { Insertion sequence } \\ \text { LAB } & \text { Lactic acid bacteria } \\ \text { L-HycDH } & \text { L-hydroxyacid dehydrogenase } \\ \text { PTA } & \text { Phosphotransacylase } \\ \text { RCR } & \text { Rolling circle replication }\end{array}$




\section{Appendix A}

Table A1. The plasmids of Streptococcus thermophilus.

\begin{tabular}{|c|c|c|c|c|c|c|c|c|c|c|c|c|c|}
\hline $\begin{array}{l}\text { Plasmid } \\
\text { Name }\end{array}$ & Strain & Replication & $\begin{array}{l}\text { Size } \\
(\mathbf{k b})\end{array}$ & $(\mathrm{G}+\mathrm{C}) \%$ & Protein & Gene & Pseudogene & Rep Protein & Mob Protein & Function & $\begin{array}{c}\text { NCBI } \\
\text { Accession }\end{array}$ & Ref. & Source \\
\hline pK1002C2 & $\mathrm{K} 1002 \mathrm{C} 2$ & & 3.38 & 35 & 2 & 2 & - & RepA 314 aa & & Small heat shock protein & NC_019231.1 & [12] & \\
\hline pK2007C6 & K2007C6 & & 2.98 & 35.1 & 2 & 2 & - & RepA 314 aa & & Small heat shock protein & NC_019232.1 & [12] & \\
\hline pSTER_A & LMD-9 & $\mathrm{RCR}$ & 4.45 & 37 & 4 & 4 & - & & & $\begin{array}{l}\text { DNA segregation ATPase } \\
\text { FtsK/SpoIIIE or related protein }\end{array}$ & NC_008500.1 & [25] & Yogurt \\
\hline pSTER_B & LMD-9 & RCR & 3.36 & 35.1 & 2 & 2 & - & $\operatorname{Rep} 314$ aa & & Small heat shock protein & NC_008501.1 & {$[25]$} & Yogurt \\
\hline pER341 & ST134 & $\mathrm{RCR}$ & 2.798 & 33.7 & & 2 & & & & & AF019139.1 & {$[31]$} & $\begin{array}{l}\text { An in-house } \\
\text { culture } \\
\text { collection }\end{array}$ \\
\hline pCI65st & NDI-6 & $\mathrm{RCR}$ & 6.5 & 34.5 & 5 & 5 & & RepA 315 aа & & Small heat shock protein; enolase & AF027167.1 & [32] & $\begin{array}{c}\text { Indian } \\
\text { fermented milk } \\
\text { dahi }\end{array}$ \\
\hline pND103 & ST2-1 & & 3.53 & 32.4 & 4 & 4 & - & & & & NC_004747.1 & {$[33]$} & \\
\hline pSt0 & St0 & $\mathrm{RCR}$ & 8.1 & 37 & 6 & 6 & & & & $\begin{array}{l}\text { Cytosine-specific } \\
\text { methyltransferase; type II } \\
\text { restriction endonuclease }\end{array}$ & NC_025154 & [34] & Dairy product \\
\hline $\mathrm{pSt} 04$ & St04 & $\mathrm{RCR}$ & 3.1 & & & & & & & Small heat shock protein & AJ242477 & {$[34]$} & Dairy product \\
\hline $\mathrm{pSt} 08$ & St08 & $\mathrm{RCR}$ & 7.51 & & 9 & 1 & & $\operatorname{Rep} 313$ aа & & $\begin{array}{l}\text { Putative adenine specific } \\
\text { methyl transferase }\end{array}$ & AJ 239049 & {$[34]$} & Dairy product \\
\hline pSt106 & & & 5.283 & 36 & & 1 & & Rep 287 aa & & Putative resolvase & AJ 242479 & [34] & Dairy product \\
\hline pJ34 & $\mathrm{J} 34$ & $\mathrm{RCR}$ & 3.38 & & & 1 & & RepA 315 аa & & & AJ242475 & {$[34]$} & Dairy product \\
\hline pSt22-2 & St22 & & & & & & & & & & & {$[34]$} & Dairy product \\
\hline pER1-1 & & $\mathrm{RCR}$ & 3.365 & & 2 & 1 & & RepA 314 aа & & Small heat shock protein & AJ 242476 & {$[34]$} & Dairy product \\
\hline pER1-2 & & & 4.45 & 36.9 & 5 & 5 & & & & & NC_025196.1 & [34] & Dairy product \\
\hline pt38 & ST2783 & & 2.91 & 32.4 & 5 & 9 & - & $\operatorname{Rep} 311$ aa & & & NC_005098.1 & [35] & $\begin{array}{c}\text { Bulgarian } \\
\text { yogurt }\end{array}$ \\
\hline pER16 & & & 4.27 & & 3 & & & Rep 315 aа & & Small heat shock protein & AF177166 & [37] & \\
\hline
\end{tabular}


Table A1. Cont.

\begin{tabular}{|c|c|c|c|c|c|c|c|c|c|c|c|c|c|}
\hline $\begin{array}{l}\text { Plasmid } \\
\text { Name }\end{array}$ & Strain & Replication & $\begin{array}{l}\text { Size } \\
(\mathbf{k b})\end{array}$ & $(\mathrm{G}+\mathrm{C}) \%$ & Protein & Gene & Pseudogene & Rep Protein & Mob Protein & Function & $\begin{array}{c}\text { NCBI } \\
\text { Accession }\end{array}$ & Ref. & Source \\
\hline pER35 & ST135 & & 9.53 & 36.5 & 5 & 5 & - & RepA 315 aa & & $\begin{array}{l}\text { Small heat shock protein; type IC } \\
\text { restriction subunit; type IC } \\
\text { modification subunit; type IC } \\
\text { modification subunit }\end{array}$ & NC_000937.1 & [37] & \\
\hline pER36 & ST136 & & 3.5 & 34.4 & 2 & 2 & - & RepA 315 aa & & Small heat shock protein & NC_000938.1 & {$[37]$} & \\
\hline pSMQ172 & SMQ-172 & RCR & 4.23 & 38 & 4 & 5 & - & Rep 223 aa & Mob 499 aa & & NC_004958.1 & {$[38]$} & \\
\hline pSMQ-316 & & $\theta$ & 6.71 & 37.7 & 5 & 5 & - & & & Primase-helicase; integrase & NC_010859.1 & [39] & \\
\hline pSMQ-312b & & $\theta$ & & & & & & & & & & [39] & \\
\hline pSMQ173b & SMQ-173 & $\mathrm{RCR}$ & 4.45 & 37 & 5 & 5 & - & Rep 146 aa & & & NC_005323.1 & [102] & \\
\hline pSMQ-308 & & & 8.14 & 37.8 & 6 & 6 & - & & & & NC_005322.1 & [102] & \\
\hline pER371 & ST371 & & 2.67 & 38.2 & 3 & 3 & - & Rep 247 aa & & & NC_004968.1 & [103] & \\
\hline pER13 & ST113 & RCR & 4.14 & 38.4 & 4 & 4 & - & RepB 217 aа & Mob 499 aa & & NC_002776.1 & [104] & \\
\hline
\end{tabular}

$\mathrm{RCR}$, rolling circle replication. 


\section{References}

1. Adolfsson, O.; Meydani, S.N.; Russell, R.M. Yogurt and gut function. Am. J. Clin. Nutr. 2004, 80, $245-256$. [PubMed]

2. Iyer, R.; Tomar, S.K.; Maheswari, T.U.; Singh, R. Streptococcus thermophilus strains: Multifunctional lactic acid bacteria. Int. Dairy J. 2010, 20, 133-141. [CrossRef]

3. Vaningelgem, F.; Zamfir, M.; Mozzi, F.; Adriany, T.; Vancanneyt, M. Biodiversity of exopolysaccharides produced by Streptococcus thermophilus strains is reflected in their production and their molecular and functional characteristics. Appl. Environ. Microbiol. 2004, 70, 900-912. [CrossRef] [PubMed]

4. Hols, P.; Hancy, F.; Fontaine, L.; Grossiord, B.; Prozzi, D. New insights in the molecular biology and physiology of Streptococcus thermophilus revealed by comparative genomics. FEMS Microbiol. Rev. 2005, 29, 435-463. [PubMed]

5. Zotta, T.; Ricciardi, A.; CiociaI, F.; Rossano, R.; Parente, E. Diversity of stress responses in dairy thermophilic streptococci. Int. J. Food Microbiol. 2008, 124, 34-42. [CrossRef] [PubMed]

6. Galia, W.; Perrin, C.; Genay, M. Variability and molecular typing of Streptococcus thermophilus strains displaying different proteolytic and acidifying properties. Int. Dairy J. 2009, 19, 89-95. [CrossRef]

7. Vuyst, L.D.; Weckx, S.; Ravyts, F.; Herman, L.; Leroy, F. New insights into the exopolysaccharide production of Streptococcus thermophilus. Int. Dairy J. 2011, 21, 586-591. [CrossRef]

8. Miclo, L.; Roux, É.; Genay, M.; Brusseaux, É.; Poirson, C.; Jameh, N.; Perrin, C.; Dary, A. Variability of hydrolysis of $\beta-, \alpha_{\mathrm{s}^{-}}$, and $\alpha_{\mathrm{s} 2}$-Caseins by 10 strains of Streptococcus thermophilus and resulting bioactive peptides. J. Agric. Food Chem. 2012, 60, 554-565. [CrossRef] [PubMed]

9. Rossi, F.; Marzotto, M.; Cremonese, S.; Rizzotti, L.; Torriani, S. Diversity of Streptococcus thermophilus in bacteriocin production, inhibitory spectrum and occurrence of thermophilin genes. Food Microbiol. 2013, 35, 27-33. [CrossRef] [PubMed]

10. Bolotin, A.; Quinquis, B.; Renault, P.; Sorokin, A.; Ehrlich, S.D.; Kulakauskas, S.; Lapidus, A.; Goltsman, E.; Mazur, M.; Pusch, G.D.; et al. Complete sequence and comparative genome analysis of the dairy bacterium Streptococcus thermophilus. Nat. Biotechnol. 2004, 22, 1554-1558. [CrossRef] [PubMed]

11. Delorme, C.; Bartholini, C.; Luraschi, M.; Pons, N.; Loux, V.; Almeida, M.; Guédon, E.; Gibrat, J.F.; Renault, P. Complete genome sequence of the pigmented Streptococcus thermophilus strain JIM8232. J. Bacteriol. 2011, 193, 5581-5582. [CrossRef] [PubMed]

12. Makarova, K.; Slesarev, A.; Wolf, Y.; Sorokin, A.; Mirkin, B.; Koonin, E.; Pavlov, A.; Pavlova, N.; Karamychev, V.; Polouchine, N.; et al. Comparative genomics of the lactic acid bacteria. Proc. Natl. Acad. Sci. USA 2006, 103, 15611-15616. [CrossRef] [PubMed]

13. Sun, Z.; Chen, X.; Wang, J.; Zhao, W.; Shao, Y.; Wu, L.; Zhou, Z.; Sun, T.; Wang, L.; Meng, H.; et al. Complete genome sequence of Streptococcus thermophilus strain ND03. J. Bacteriol. 2011, 193, 793-794. [CrossRef] [PubMed]

14. Kang, X.; Ling, N.; Sun, G.; Zhou, Q.; Zhang, L.; Sheng, Q. Complete genome sequence of Streptococcus thermophilus strain MN-ZLW-002. J. Bacteriol. 2012, 194, 4428-4429. [CrossRef] [PubMed]

15. Wu, Q.; Tun, H.M.; Leung, F.C.; Shah, N.P. Genomic insights into high exopolysaccharide-producing dairy starter bacterium Streptococcus thermophilus ASCC 1275. Sci. Rep. 2014, 4, 4974. [CrossRef] [PubMed]

16. Labrie, S.J.; Tremblay, D.M.; Plante, P.L.; Wasserscheid, J.; Dewar, K.; Corbeil, J.; Moineau, S. Complete genome sequence of Streptococcus thermophilus SMQ-301, a model strain for phage-post interactions. Genome Announc. 2015, 3, e00480-15. [CrossRef] [PubMed]

17. Shi, Y.; Chen, Y.; Li, Z.; Yang, L.; Chen, W.; Mu, Z. Complete genome sequence of Streptococcus thermophilus MN-BM-A02, a rare strain with a high acid-producing rate and low post-acidification ability. Genome Announc. 2015, 3, e00979-15. [CrossRef] [PubMed]

18. Bai, Y.; Sun, E.; Shi, Y.D.; Jiang, Y.Y.; Chen, Y.; Liu, S.L.; Zhao, L.; Zhang, M.; Guo, H.Y.; Zhang, H.; et al. Complete genome sequence of Streptococcus thermophilus MN-BM-A01, a strain with high exopolysaccharides production. J. Biotechnol. 2016, 224, 45-46. [CrossRef] [PubMed]

19. Treu, L.; Vendramin, V.; Bovo, B.; Campanaro, S.; Corich, V.; Giacomini, A. Genome sequences of Streptococcus thermophilus strains MTH17CL396 and M17PTZA496 from Fontina, an Italian PDO cheese. Genome Announc. 2014, 2, e00067-14. [CrossRef] [PubMed] 
20. Treu, L.; Vendramin, V.; Bovo, B.; Campanaro, S.; Corich, V.; Giacominia, A. Whole-genome sequences of Streptococcus thermophilus strains TH1435 and TH1436, isolated from raw goat milk. Genome Announc. 2014, 2, e01129-13. [CrossRef] [PubMed]

21. Treu, L.; Vendramin, V.; Bovo, B.; Campanaro, S.; Corich, V.; Giacomini, A. Genome sequences of four Italian Streptococcus thermophilus strains of dairy origin. Genome Announc. 2014, 2, e00126-14. [CrossRef] [PubMed]

22. Prajapati, J.B.; Nathani, N.M.; Patel, A.K.; Senan, S.; Joshi, C.G. Genomic analysis of dairy starter culture Streptococcus thermophilus MTCC 5461. J. Microbiol. Biotechnol. 2013, 23, 459-466. [CrossRef] [PubMed]

23. Barrangou, R.; Coute-Monvoisin, A.C.; Stahl, B.; Chavichvily, I.; Damange, F.; Romero, D.A.; Boyaval, P.; Fremaux, C.; Horvath, P. Genomic impact of CRISPR immunization against bacteriophages. Biochem. Soc. Trans. 2013, 41, 1383-1391. [CrossRef] [PubMed]

24. Wels, M.; Serrano, L.M.; Eibrink, B.J.; Backus, L.; Bongers, R.S.; Vriesendorp, B.; Siezen, R.J.; van Hijum, S.A.; Meijer, W.C. Draft genome sequence of Streptococcus thermophilus C106, a dairy isolate from an artisanal cheese produced in the countryside of Ireland. Genome Announc. 2015, 3, e01377-15. [CrossRef] [PubMed]

25. Goh, Y.J.; Goin, C.; O'Flaherty, S.; Altermann, E.; Hutkins, R. Specialized adaptation of a lactic acid bacterium to the milk environment: The comparative genomics of Streptococcus thermophilus LMD-9. Microb. Cell Factories 2011, 10 (Suppl. 1), 10066-10071. [CrossRef] [PubMed]

26. Eng, C.; Thibessard, A.; Danielsen, M.; Rasmussen, T.B.; Mari, J.F.; Leblond, P. In silico prediction of horizontal gene transfer in Streptococcus thermophilus. Arch. Microbiol. 2011, 193, 287-297. [CrossRef] [PubMed]

27. Liu, M.J.; Siezen, R.J.; Nauta, A. In silico prediction of horizontal gene transfer events in Latobacillus bulgaricus and Streptococcus thermophilus reveals protocooperation in yogurt manufacturing. Appl. Environ. Microbiol. 2009, 75, 4120-4129. [CrossRef] [PubMed]

28. Rasmussen, T.B.; Danielsen, M.; Valina, O.; Garrigues, C.; Johansen, E.; Pedersen, M.B. Streptococcus thermophilus core genome: Comparative genome hybridization study of 47 strains. Appl. Environ. Microbiol. 2008, 74, 4703-4710. [CrossRef] [PubMed]

29. Cui, Y.H.; Hu, T.; Qu, X.J.; Zhang, L.W.; Ding, Z.Q.; Dong, A.J. Plasmids from food lactic acid bacteria: Diversity, similarity, and new developments. Int. J. Mol. Sci. 2015, 16, 13172-13202. [CrossRef] [PubMed]

30. Mercenier, A. Molecular genetics of Streptococcus thermophilus. FEMS Microbiol. Rev. 1990, 87, 61-78. [CrossRef]

31. Somkuti, G.A.; Solaiman, D.K.Y.; Steinberg, D.H. Structural and functional properties of the hsp16.4-bearing plasmid pER341 in Streptococcus thermophilus. Plasmid 1998, 40, 61-72. [CrossRef] [PubMed]

32. O'Sullivan, T.; van Sinderen, D.; Fitzgerald, G. Structural and functional analysis of pCI65st, a $6.5 \mathrm{~kb}$ plasmid from Streptococcus thermophilus NDI-6. Microbiology 1999, 145, 127-134. [CrossRef] [PubMed]

33. Su, P.; Jury, K.; Allison, G.E.; Wong, W.Y.; Kim, W.S.; Liu, C.Q.; Vancov, T.; Dunn, N.W. Cloning vectors for Streptococcus thermophilus derived from a native plasmid. FEMS Microbiol. Lett. 2002, 216, 43-47. [CrossRef] [PubMed]

34. Geis, A.E.; Demerdash, H.A.M.; Heller, K.J. Sequence analysis and characterization of plasmids from Streptococcus thermophilus. Plasmid 2003, 50, 53-69. [CrossRef]

35. Petrova, P.; Miteva, V.; Ruiz-Maso, J.A.; Solar, G.D. Structural and functional analysis of pt38, a $2.9 \mathrm{~kb}$ plasmid of Streptococcus thermophilus yoghurt strain. Plasmid 2003, 50, 176-189. [CrossRef]

36. Somkuti, G.A.; Steinberg, D.H. Promoter activity of the pER341-borne STphsp in heterologous gene expression in E. coli and Streptococcus thermophilus. FEMS Microbiol. Lett. 1999, 179, 431-436. [CrossRef] [PubMed]

37. Solow, B.T.; Somkuti, G.A. Comparison of low-molecular-weight heat stress proteins encoded on plasmids in different strains of Streptococcus thermophilus. Curr. Microbiol. 2000, 41, 177-181. [CrossRef] [PubMed]

38. Turgeon, N.; Moineau, S. Isolation and characterization of a Streptococcus thermophilus plasmid closely related to the pMV158 family. Plasmid 2001, 45, 171-183. [CrossRef] [PubMed]

39. Girard, S.L.; Moineau, S. Analysis of two A-replicating plasmids of Streptococcus thermophilus. Plasmid 2007, 58, 174-181. [CrossRef] [PubMed]

40. O'Leary, V.S.; Woychik, J.H. Utilization of lactose, glucose, and galactose by a mixed culture of Streptococcus thermophilus and Lactobacillus bulgaricus in milk treated with lactase enzyme. Appl. Environ. Microbiol. 1976, 32, 89-94. [PubMed]

41. Tinson, W.; Ratcliff, M.F.; Hillier, A.J.; Jago, G.R. Metabolism of Streptococcus thermophilus. 3. Influence on the level of bacterial metabolites in Cheddar cheese. Aust. J. Dairy Technol. 1982, 37, 17-21. 
42. De Vin, F.; Rådström, P.; Herman, L.; de Vuyst, L. Molecular and biochemical analysis of the galactose phenotype of dairy Streptococcus thermophilus strains reveals four different fermentation profiles. J. Appl. Microbiol. 2005, 71, 3659-3667. [CrossRef] [PubMed]

43. Mukherjee, K.K. Isolation of galactose-fermenting thermophilic cultures and their use in the manufacture of low browning Mozzarella cheese. J. Dairy Sci. 1994, 77, 2839-2849. [CrossRef]

44. Giraffa, G.; Paris, A.; Valcavi, L.; Gatti, M.; Neviani, E. Genotypic and phenotypic heterogeneity of Streptococcus thermophilus strains isolated from dairy products. J. Appl. Microbiol. 2001, 91, 937-943. [CrossRef] [PubMed]

45. Mora, D.; Fortina, M.G.; Parini, C.; Ricci, G.; Gatti, M.; Giraffa, G.; Manachini, P.L. Genetic diversity and technological properties of Streptococcus thermophilus strains isolated from dairy products. J. Appl. Microbiol. 2002, 93, 278-287. [CrossRef] [PubMed]

46. Morandi, S.; Brasca, M. Safety aspects, genetic diversity and technological characterisation of wild-type Streptococcus thermophilus strains isolated from north Italian traditional cheeses. Food Control 2012, 23, $203-209$. [CrossRef]

47. Erkus, O.; Okuklu, B.; Yenidunya, A.F.; Harsa, S. High genetic and phenotypic variability of Streptococcus thermophilus strains isolated from artisanal Yuruk yoghurts. LWT-Food Sci. Technol. 2014, 58, 348-354. [CrossRef]

48. Thomas, M.; Wrzosek, L.; Ben-Yahia, L.; Noordine, M.-L.; Gitton, C.; Chevret, D.; Langella, P.; Mayeur, C.; Cherbuy, C.; Rul, F. Carbohydrate metabolism is essential for the colonization of Streptococcus thermophilus in the digestive tract of gnotobiotic rats. PLoS ONE 2011, 6, e28789. [CrossRef] [PubMed]

49. Maxwell, E.S.; Kurahasi, K.; Kalckar, H.M. Enzymes of the Leloir pathway. Methods Enzymol. 1962, 5, $174-189$.

50. Vaughan, E.E.; van den Bogaard, P.T.; Catzeddu, P.; Kuipers, O.P.; de Vos, W.M. Actiation of silent gal genes in the lac-gal regulon of Streptococcus thermophilus. J. Bacteriol. 2001, 183, 1184-1194. [CrossRef] [PubMed]

51. Vaillancourt, K.; LeMay, J.D.; Lamoureux, M.; Frenette, M.; Moineau, S.; Vadeboncoeur, C. Characterization of a galactokinase-positive recombinant strain of Streptococcus thermophilus. Appl. Environ. Microbiol. 2004, 70, 4596-4603. [CrossRef] [PubMed]

52. Van den Bogaard, R.T.C.; Hols, P.; Kuipers, O.P.; Kleerebezem, M.; de Vos, W.M. Sugar utilisation and conservation of the gal-lac gene cluster in Streptococcus thermophilus. Syst. Appl. Microbiol. 2004, 27, 10-17. [CrossRef] [PubMed]

53. Anbukkarasi, K.; Nanda, D.K.; UmaMaheswari, T.; Hemalatha, T.; Singh, P.; Singh, R. Assessment of expression of Leloir pathway genes in wild-type galactose-fermenting Streptococcus thermophilus by real-time PCR. Eur. Food Res. Technol. 2014, 239, 895-903. [CrossRef]

54. Sørensen, K.I.; Curic-Bawden, M.; Junge, M.P.; Janzen, T.; Johansen, E. Enhancing the sweetness of yoghurt through metabolic remodeling of carbohydrate metabolism in Streptococcus thermophilus and Lactobacillus delbrueckii subsp. bulgaricus. Appl. Environ. Microbiol. 2016, 82, 3683-3692. [CrossRef] [PubMed]

55. Levander, F.; Rådström, P. Requirement for phosphoglucomutase in exopolysaccharide biosynthesis in glucose- and lactose-utilizing Streptococcus thermophilus. Appl. Environ. Microbiol. 2001, 67, 2734-2738. [CrossRef] [PubMed]

56. Levander, F.; Svensson, M.; Rådström, P. Enhanced exopolysaccharide production by metabolic engineering of Streptococcus thermophilus. Appl. Environ. Microbiol. 2002, 68, 784-790. [CrossRef] [PubMed]

57. Hirasuka, Y.; Li, G. Alcohol and eye diseases: A review of epidemiologic studies. J. Stud. Alcohol. 1992, 62, 372-402.

58. Broadbent, J.R.; Mcmahon, D.J.; Welker, D.L.; Oberg, C.J.; Moineau, S. Biochemistry, genetics, and applications of exopolysaccharide production in Streptococcus thermophilus: A review. J. Dairy Sci. 2003, 86, 407-423. [CrossRef]

59. Hassan, A.N.; Frank, J.F.; Schmidt, K.A.; Shalab, S.I. Rheological properties of yogurt made with encapsulated non ropy lactic cultures. J. Dairy Sci. 1996, 79, 2091-2097. [CrossRef]

60. Bhaskaracharya, R.K.; Shah, N.P. Texture characteristics and microstructure of skim milk mozzarella cheeses made using exopolysaccharide or non-exopolysaccharide producing starter cultures. Aust. J. Dairy Technol. 2000, 55, 132-138.

61. Amatayakul, T.; Sherkat, F.; Shah, N.P. Syneresis in set yogurt as affected by EPS starter cultures and levels of solids. Int. J. Dairy Technol. 2006, 59, 216-221. [CrossRef] 
62. Purwandari, U.; Shah, N.P.; Vasiljevic, T. Effects of exopolysaccharide producing strains of Streptococcus thermophilus on technological and rheological properties of set-type yoghurt. Int. Dairy J. 2007, 17, 1344-1352. [CrossRef]

63. Marcial, G.; Messing, J.; Menchicchi, B.; Goycoolea, F.M.; Faller, G.; de Valdez Graciela, F.; Hensel, A. Effects of polysaccharide isolated from Streptococcus thermophilus CRL1190 on human gastric epithelial cells. Int. J. Biol. Macromol. 2013, 62, 217-224. [CrossRef] [PubMed]

64. Ren, W.; Xia, Y.; Wang, G.; Zhang, H.; Zhu, S.; Ai, L. Bioactive exopolysaccharides from a S. thermophilus strain: Screening, purification and characterization. Int. J. Biol. Macromol. 2016, 86, 402-407. [CrossRef] [PubMed]

65. Rodríguez, C.; Medici, M.; Mozzi, F.; de Valdez Graciela, F. Therapeutic effect of Streptococcus thermophilus CRL 1190-fermented milk on chronic gastritis. World J. Gastroenterol. 2010, 16, 1622-1630. [CrossRef] [PubMed]

66. Ruas-Madiedo, P.; Abraham, A.; Mozzi, F.; Los Reyes-Gavilán, C.G.D. Functionality of exopolysaccharides produced by lactic acid bacteria. In Molecular Aspects of Lactic Acid Bacteria for Traditional and New Applications; Mayo, B., López, P., Pérez-Martínez, G., Eds.; Research Signpost: Kerala, India, 2008; pp. 137-166.

67. Laws, A.; Gu, Y.C.; Marshall, V. Biosynthesis, characterisation and design of bacterial exopolysaccharides from lactic acid bacteria. Biotechnol. Adv. 2001, 19, 597-625. [CrossRef]

68. Zhang, J.; Cao, Y.; Wang, J.; Guo, X.; Zheng, Y.; Zhao, W.; Mei, X.; Guo, T.; Yang, Z. Physicochemical characteristics and bioactivities of the exopolysaccharide and its sulphated polymer from Streptococcus thermophilus GST-6. Carbohydr. Polym. 2016, 146, 368-375. [CrossRef] [PubMed]

69. Mozzi, F.; Vaningelgem, F.; Hebert, E.M.; Meulen, R.V.D.; Moreno, M.R.F.; Valdez, G.F.D.; Vuyst, L.D. Diversity of heteropolysaccharide-producing lactic acid bacterium strains and their biopolymers. Appl. Environ. Microbiol. 2006, 72, 4431-4435. [CrossRef] [PubMed]

70. Jolly, L.; Stingele, F. Molecular organization and functionality of exopolysaccharide gene clusters in lactic acid bacteria. Int. Dairy J. 2001, 11, 733-745. [CrossRef]

71. Stingele, F.; Neeser, J.R.; Mollet, B. Identification and characterization of the eps (exopolysaccharide) gene cluster from Streptococcus thermophilus Sfi6. J. Bacteriol. 1996, 178, 1680-1690. [PubMed]

72. Kranenburg, R.V.; Marugg, J.D.; Swam, I.I.V.; Willem, N.J.; Devos, W.M. Molecular characterization of the plasmid encoded eps gene cluster essential for exopolysaccharide biosynthesis in Lactococcus lactis. Mol. Microbiol. 1997, 24, 387-397. [CrossRef] [PubMed]

73. Bourgoin, F.; Pluvinet, A.; Gintz, B.; Decaris, B.; Guédon, G. Are horizontal transfers involved in the evolution of the Streptococcus thermophilus exopolysaccharide synthesis loci? Gene 1999, 233, 151-161. [CrossRef]

74. Stingele, F.; Vincent, S.J.F.; Faber, E.J.; Newell, J.W.; Kamerling, J.P.; Neeser, J.R. Introduction of the exopolysaccharide gene cluster from Streptococcus thermophilus, Sfi6 into Lactococcus lactis, MG1363: Production and characterization of an altered polysaccharide. Mol. Microbiol. 1999, 32, 1287-1295. [CrossRef] [PubMed]

75. Van Kranenburg, R.; Vos, H.R.; Swam, I.I.V.; Kleerebezem, M.; de Vos, W.M. Functional analysis of glycosyltransferase genes from Lactococcus lactis and other gram-positive cocci: Complementation, expression, and diversity. J. Bacteriol. 1999, 181, 6347-6353. [PubMed]

76. Ruas-Madiedo, P.; Los Reyes-Gavilán, C.G.D. Invited Review: Methods for the screening, isolation, and characterization of exopolysaccharides produced by lactic acid bacteria. J. Dairy Sci. 2005, 88, 843-856. [CrossRef]

77. Zisu, B.; Shah, N.P. Effects of $\mathrm{pH}$, temperature, supplementation with whey protein concentrate, and adjunct cultures on the production of exopolysaccharides by Streptococcus thermophilus 1275. J. Dairy Sci. 2003, 86, 3405-3415. [CrossRef]

78. Amatayakul, T.; Sherkat, F.; Shah, N.P. Physical characteristics of set yoghurt made with altered casein to whey protein ratios and EPS-producing starter cultures at 9 and 14\% total solids. Food Hydrocoll. 2006, 20, 314-324. [CrossRef]

79. Zisu, B.; Shah, N.P. Low-fat mozzarella as influenced by microbial exopolysaccharides, preacidification, and whey protein concentrate. J. Dairy Sci. 2005, 88, 1973-1985. [CrossRef]

80. Degeest, B.; Vaningelgem, F.; Vuyst, L.D. Microbial physiology fermentation kinetics, and process engineering of heteropolysaccharide production by lactic acid bacteria. Int. Dairy J. 2001, 11, 747-757. [CrossRef] 
81. Li, D.; Li, J.; Zhao, F.; Wang, G.H.; Qin, Q.Q.; Hao, Y.L. The influence of fermentation condition on production and molecular mass of EPS produced by Streptococcus thermophilus 05-34 in milk-based medium. Food Chem. 2016, 197, 367-372. [CrossRef] [PubMed]

82. Pébay, M.; Colmin, C.; Guédon, G.; Simonet, J.M.; Decaris, B. Chromosomal genetic instability in S. thermophilus. Lait Dairy Sci. Technol. 1993, 73, 181-190. [CrossRef]

83. Savijoki, K.; Ingmer, H.; Varmanen, P. Proteolytic systems of lactic acid bacteria. Appl. Microbiol. Biotechnol. 2006, 71, 394-406. [CrossRef] [PubMed]

84. Christensen, J.E.; Dudley, E.G.; Pederson, J.A.; Steele, J.L. Peptidases and amino acid catabolism in lactic acid bacteria. Antonie Van Leeuwenhoek 1999, 76, 217-246. [CrossRef] [PubMed]

85. Shihata, A.; Shah, N.P. Proteolytic profiles of yogurt and probiotic bacteria. Int. Dairy J. 2000, 10, 401-408. [CrossRef]

86. Liu, M.J.; Bayjanov, J.R.; Renckens, B.; Nauta, A.; Siezen, R.J. The proteolytic system of lactic acid bacteria revisited: A genomic comparison. BMC Genom. 2010, 11, 1-15. [CrossRef] [PubMed]

87. Settachaimongkon, S.; Nout, M.J.R.; Fernandes, E.C.A.; Hettinga, K.A.; Vervoort, J.M.; van Hooijdonk, T.C.M.; Zwietering, M.H.; Smid, E.J.; van Valenberg, H.J.F. Influence of different proteolytic strains of Streptococcus thermophilus in co-culture with Lactobacillus delbrueckii subsp. bulgaricus on the metabolite profile of set-yoghurt. Int. J. Food Microbiol. 2014, 177, 29-36. [CrossRef] [PubMed]

88. Chang, O.K.; Perrin, C.; Galia, W.; Saulnier, F.; Miclo, L.; Roux, E.; Driou, A.; Humbert, G.; Dary, A. Release of the cell-envelope protease PrtS in the growth medium of Streptococcus thermophilus 4F44. Int. Dairy J. 2012, 23, 91-98. [CrossRef]

89. Shahbal, S.; Hemme, D.; Desmazeaud, M. High cell wall-associated proteinase activity of some Streptococcus thermophilus strains (H-strains) correlated with a high acidification rate in milk. Le Lait 1991, 71, 351-357. [CrossRef]

90. Mora, D.; Ricci, G.; Guglielmetti, S.; Daffonchio, D.; Fortina, M.G. 16S-23S rRNA intergenic spacer region sequence variation in Streptococcus thermophilus and related dairy streptococci and development of a multiplex ITS-SSCP analysis for their identification. Microbiology 2003, 149, 807-813. [CrossRef] [PubMed]

91. Cheng, H. Volatile flavor compounds in yogurt: A review. Crit. Rev. Food Sci. Nutr. 2010, 50, 938-950. [CrossRef] [PubMed]

92. Ott, A.; Fay, L.B.; Chaintreau, A. Determination and origin of the aroma impact compounds of yogurt flavor. J. Agric. Food Chem. 1997, 45, 850-858. [CrossRef]

93. Imhof, R.; Bosset, J.O. Relationships between microorganisms and formation of aroma compounds in fermented dairy products. Z. Lebensm. Unters. Forsch. 1994, 198, 267-276. [CrossRef]

94. Liu, M.J.; Nauta, A.; Francke, C.; Siezen, R.J. Comparative genomics of enzymes in flavor-forming pathways from amino acids in lactic acid bacteria. Appl. Environ. Micobol. 2008, 74, 4590-4600. [CrossRef] [PubMed]

95. Yvon, M.; Rijnen, L. Cheese flavour formation by amino acid catabolism. Int. Dairy J. 2001, 11, $185-201$. [CrossRef]

96. Smit, G.; Smit, B.A.; Engels, W.J.M. Flavour formation by lactic acid bacteria and biochemical flavour profiling of cheese products. FEMS Microbiol. Rev. 2005, 29, 591-610. [CrossRef] [PubMed]

97. Ardo, Y. Flavour formation by amino acid catabolism. Biotechnol. Adv. 2006, 24, 238-242. [CrossRef] [PubMed]

98. Helinck, S.; Le Bars, D.; Moreau, D.; Yvon, M. Ability of thermophilic lactic acid bacteria to produce aroma compounds from amino acids. Appl. Environ. Micobol. 2004, 70, 3855-3861. [CrossRef] [PubMed]

99. Akyol, I.; Ozcelik, F.G.; Karakas-Sen, A.; Ozkose, E.; Gezginc, Y.; Ekinci, M.S. Cloning and over expression of the als, pflA, and adhB genes in Streptococcus thermophilus and their effects on metabolite formation. Mol. Biotechnol. 2015, 57, 923-930. [CrossRef] [PubMed]

100. Liu, W.J. Characteristics of Acid and Flavor-Producing Stretococcus thermophilus and Lactobacillus bulgaricus, as well as Their Functional Gene Typing and Expression. Ph.D. Thesis, Inner Mongolia Agricultural University, Hohhot, China, 2014.

101. Liu, W.J.; Yu, J.; Sun, Z.H.; Song, Y.Q.; Wang, X.N.; Wang, H.M.; Wuren, T.Y.; Zha, M.S.; Menghe, B.; Zhang, H.P. Relationships between functional genes in Lactobacillus delbrueckii ssp. bulgaricus isolates and phenotypic characteristics associated with fermentation time and flavor production in yogurt elucidated using multilocus sequence typing. J. Dairy Sci. 2016, 99, 89-103. [PubMed] 
102. Turgeon, N.; Frenette, M.; Moineau, S. Characterization of a $\theta$-replicating plasmid from Streptococcus thermophilus. Plasmid 2004, 51, 24-36. [CrossRef] [PubMed]

103. Solaiman, D.K.; Somkuti, G.A. Characterization of a novel Streptococcus thermophilus rolling-circle plasmid used for vector construction. Appl. Microbiol. Biotechnol. 1998, 50, 174-180. [CrossRef] [PubMed]

104. Somkuti, G.A.; Steinberg, D.H. Molecular organization of plasmid pER13 in Streptococcus thermophilus. Biotechnol. Lett. 2007, 29, 1991-1999. [CrossRef] [PubMed]

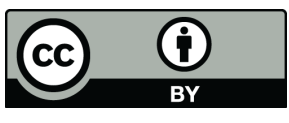

(C) 2016 by the authors; licensee MDPI, Basel, Switzerland. This article is an open access article distributed under the terms and conditions of the Creative Commons Attribution (CC-BY) license (http://creativecommons.org/licenses/by/4.0/). 